\title{
IMPLEMENTASI SISTEM UNTUK PREDIKSI HARGA EMAS
}

\author{
Bayu Pratama Nugroho \\ Program Studi Sistem Informasi \\ Sekolah Tinggi Manajemen Informatika dan Komputer (STMIK) Palangka Raya \\ Jln. G. Obos, No. 114, Palangka Raya, Kalimantan Tengah \\ Email : bayupratamanugroho@yahoo.com
}

\begin{abstract}
This state of economic instability prompted many people, organizations and companies to invest in gold precious metals. Factors affecting the increase or decrease in gold prices are changes in the dollar exchange rate against the rupiah, the world political situation, the domestic economic situation, and interest rates.

The method used in this case is K-Nearest Neighbor method that is used in the training phase, the algorithm only maintain classification features and classification of training data samples. At the classification stage, the same feature is calculated for testing the data.

The results obtained successfully make the application for the prediction of gold prices by utilizing the method of Nearest Neighbor Retrieval. This application can help users in knowing the results of predictions of expensive or cheap gold prices with views in terms of economic situation, interest rates, political situation, and changes in exchange rates.
\end{abstract}

Keywords: Application, Gold,K-Nearest Neighbor, Technology, Web

\section{PENDAHULUAN}

Kegiatan ekonomi di dunia ini tidak dapat dilepaskan dari kegiatan investasi karena dengan adanya investasi akan mendorong pertumbuhan ekonomi suatu negara. Emas merupakan salah satu komoditas investasi yang nilainya terus mengalami kenaikan dari tahun ke tahun. Kenaikan harga emas ini akan mendorong investor untuk memilih berinvestasi emas daripada pasar modal. Investasi dalam emas memberikan hasil yang lebih baik untuk jangka panjang dan dengan daya beli (purchasing power) yang lebih baik, sehingga investasi emas merupakan solusi efektif mengingat nilai uang yang setiap tahun tergerus oleh inflasi. Inflasi merupakan suatu gejala yang terjadi karena adanya ketidakstabilan ekonomi sehingga harga mengalami kenaikan secara kontinu. Keadaan seperti ketidakstabilan ekonomi inilah yang mendorong banyak orang, organisasi dan perusahaan untuk berinvestasi logam mulia emas.

Faktor - faktor yang mempengaruhi naik atau turunnya harga emas menurut (Sahabat Pengadaian, 2016) adalah perubahan kurs (nilai kurs 
dollar terhadap rupiah), situasi politik dunia, situasi ekonomi dalam negeri, dan suku bunga.

Berdasarkan permasalahan di atas, kemampuan untuk dapat memprediksi harga emas merupakan keuntungan tersendiri untuk melindungi diri dari dampak inflasi, sehingga timbul ide untuk merancang sebuah aplikasi yang dapat digunakan untuk memprediksi harga emas menggunakan metode Nearest Neighbor Retrieval. Dengan adanya sebuah kasus akan menitikberatkan pada pemecahan masalah dengan didasarkan pada pengetahuan dari kasus-kasus sebelumnya. Apabila ada kasus baru maka akan disimpan pada basis pengetahuan, kemudian sistem akan melakukan learning sehingga pengetahuan yang dimiliki oleh sistem akan bertambah.

\section{METODE}

Penelitian yang dilakukan oleh penulis meliputi beberapa tahapan :

\section{Studi Pustaka}

Penulis akan melakukan studi pustaka untuk menambah informasi serta teori untuk mendukung metode Nearest Neighbor yang akan digunakan nantinya, selain itu studi pustaka juga dilakukan untuk mendapatkan data dari emas untuk dijadikan bahan penelitian.

\section{Analisis Masalah}

Memahami cara kerja metode Nearest Neighbor untuk menyelesaikan masalah peramalan harga emas.

\section{Perancangan Sistem}

Tahap ini akan dilakukan perancangan basis data untuk menyimpan data bahan penelitian, perancangan antarmuka, dan perancangan prosedural sistem.

\section{Pengkodean}

Setelah melalui tahap perancangan, maka sistem akan mulai dibuat atau diimplementasikan dalam bahasa program.

\section{Pengujian}

Pada tahap ini akan dilakukan pengujian akurasi sistem peramalan dan mencari kesalahan program sehingga dapat segera diperbaiki dan sistem dapat berjalan sesuai harapan.

\section{Kajian Pustaka}

Penelitian ini dibuat berdasarkan referensi dari sejumlah penelitian yang ada di indonesia. Secara garis besar perkembangan teknologi informasi dalam berbagai bidang kehidupan mendorong manusia untuk 
memanfaatkan teknologi informasi. Teknologi informasi, dalam hal ini penggunaan komputer, membantu unit dalam organisasi agar pekerjaan dapat dilakukan dengan cepat dan tepat, serta dapat meminimalkan resiko kehilangan data yang rawan bagi organisasi.

Perkembangan ini dimanfaatkan pula oleh organisasi untuk mempermudah dan mempercepat pekerjaannya. Teknologi tersebut di kembangkan oleh (Sinta, 2015) dengan judul aplikasi prediksi kenaikan harga emas dunia dengan menggunakan metode backpropagation, hasil penelitiannya berupa sebuah aplikasi untuk mengetahui keakuratan metode jaringan syaraf tiruan backpropagation dalam melakukan prediksi terhadap kenaikan harga emas dunia sehingga berbeda dengan penelitian yang dilakukan oleh penulis.

Sementara (Antonyet al., 2013) dengan judul perancangan program prediksi harga emas dengan menggunakan metode adaptive neurofuzzy inference system", merupakan suatu aplikasi yang memperoleh nilai prediksi emas 1 hari kedepan dengan menggunakan metode ANFIS dan mengetahui keakuratan prediksi harga emas dengan metode ANFIS.
Kemudian (Reza, et al., 2013) dengan judul implementasi jaringan syaraf tiruan perambatan balik untuk memprediksi harga logam mulia emas menggunakan algoritma levenberg marquardt, hasil dari penelitian ini berupa aplikasi jaringan syaraf tiruan perambatan balik untuk memprediksi harga logam mulia emas dan hanya dapat digunakan secara real time.

Berdasarkan penelitianpenelitian yang pernah dilakukan terkait prediksi harga emas, maka akan dilakukan penelitian yang membahas tentang predisi harga emas dengan metode Nearest Neighbor Retrieval. Penelitian ini diharapkan dapat menangani permasalahan-permasalahan yang mencakup dengan harga emas.

\section{Emas}

Emas adalah barang yang sering menjadi investasi bagi banyak orang. Harga yang terus merangkak naik dari tahun ketahun membuat emas menjadi investasi yang paling diminati. Emas merupakan logam mulian yang paling diminati. Emas dalam hal investasi dapat berbentuk perhiasan ataupun dalam bentuk emas batangan atau sering disebut logam mulia. (Info Peluang Usaha, 2010). 
Emas adalah bentuk umum yang mewakili uang karena kejarangannya, ketahanannya, dapat dibagi-bagi, tahan terhadap jamur dan kemudahan pengindentifikasiannya,seringberhubun gan dengan perak. Perak biasanya adalah alat pembayaran yang sah, dengan emas sebagai metal untuk cadangan moneter. Sulit untuk memanipulasi standar sebuah emas untuk disesuaikan dengan kebutuhan ekonomi terhadap uang, menyediakan ketidakleluasaan praktek terhadap pengukuran yang bank sentral mungkin gunakan sebaliknya untuk memberi tanggapan pada krisis ekonomi.London Bullion Market Association (LBMA), frasa yang sering kita singgung ketika membicarakan perihal emas dan turunannya (Investasi Emas, Emas Batangan, Sertifikasi Emas, Tren Harga Emas, Pasar Emas Internasional dsb). LBMA secara tidak langsung menunjuk pada Pasar Emas Internasional yang berlokasi di London. Pasar Emas london inilah yang menjadi rujukan pasar emas global dalam menentukan patokan harga pasar emas hampir di setiap negara (termasuk dengan harga Dinar Dirham Islam)(Kesumaet al., 2012).

\section{Algoritma K-Nearest Neighbor} $(\mathrm{KKN})$
K-Nearest Neighbor (KNN)

adalah suatu metode yang menggunakanPada fase training, algoritma ini hanya melakukan penyimpanan vektor-vektor fitur dan klasifikasi data training sample. Pada fase klasifikasi, fitur-fitur yang sama dihitung untuk testing data (yang klasifikasinya tidak diketahui). Jarak dari vektor baru yang ini terhadap seluruh vektor training sample dihitung dan sejumlah $k$ buah yang paling dekat diambil. Titik yang baru klasifikasinya diprediksikan termasuk pada klasifikasi terbanyak dari titik-titik tersebut. algoritma supervised dimana hasil dari query instance yang baru diklasifikan berdasarkan mayoritas dari kategori pada KNN. Tujuan dari algoritma ini adalah mengklasifikasikan obyek baru bedasarkan atribut dan training sample.Classifier tidak menggunakan model apapun untuk dicocokkan dan hanya berdasarkan pada memori. Diberikan titik query, akan ditemukan sejumlah $\mathrm{k}$ obyek atau (titik training) yang paling dekat dengan titik query. Klasifikasi menggunakan voting terbanyak diantara klasifikasi dari $\mathrm{k}$ obyek.algoritma KNN menggunakan klasifikasi ketetanggaan sebagai nilai prediksi dari query instance yang baru. 
Algoritma metode $\mathrm{KNN}$ sangatlah sederhana, bekerja berdasarkan jarak terpendek dari query instance ke training sample untuk menentukan KNN-nya. Training sample diproyeksikan ke ruang berdimensi banyak, dimana masing-masing dimensi merepresentasikan fitur dari data. Ruang ini dibagi menjadi bagian-bagian berdasarkan klasifikasi training sample. Sebuah titik pada ruang ini ditandai kelac c jika kelas c merupakan klasifikasi yang paling banyak ditemui pada $\mathrm{k}$ buah tetangga terdekat dari titik tersebut. Dekat atau jauhnya tetangga biasanya dihitung berdasarkan Euclidean Distance yang direpresentasikan pada rumus nomor 1 berikut :

$D(a, b)=\sqrt{\sum_{k=1}^{d}\left(a_{k}-b_{k}\right)^{2}}$

Dimana matriks $\mathrm{D}(\mathrm{a}, \mathrm{b})$ adalah jarak skalar dari kedua vektor a dan b dari matriks dengan ukuran d dimensi.

Pada fase training, algoritma ini hanya melakukan penyimpanan vektorvektor fitur dan klasifikasi data training sample. Pada fase klasifikasi, fitur-fitur yang sama dihitung untuk testing data (yang klasifikasinya tidak diketahui). Jarak dari vektor baru yang ini terhadap seluruh vektor training sample dihitung dan sejumlah $\mathrm{k}$ buah yang paling dekat diambil. Titik yang baru klasifikasinya diprediksikan termasuk pada klasifikasi terbanyak dari titik-titik tersebut(Yofiyanto, 2010).

Faktor - faktor yang mempengaruhi naik atau turunnya harga emas menurut (Sahabat Pengadaian, 2016) adalah :

1) Perubahan Kurs (Nilai Kurs Dollar Terhadap Rupiah).

Melemahnya kurs dollar AS biasanya mendorong kenaikan harga emas dunia. Hal ini karena jatuhnya nilai mata uang dollar membuat harga emas menjadi lebih murah dalam mata uang lain sehingga umumnya mendorong adanya kenaikan permintaan emas, terutama dari sektor industri perhiasan. Di Indonesia, pada pertengahan tahun 2001, ketika mata uang rupiah mengalami penguatan yang cukup signifikan, harga emas logam mulia (LM) pun menurun. Demikian pula ketika rupiah melemah, harga emas LM pun meningkat. Di awal tahun 2003, perbedaan kurs USD/IDR (dollar AS terhadap rupiah) dengan harga emas LM semakin melebar karena di samping harga emas di pasaran dunia tinggi, nilai dollar AS pun melemah. 
2) Situasi Politik Dunia.

Kenaikan harga emas pada akhir tahun 2002 dan awal tahun 2003 terjadi sebagai dampak dari akan dilakukannya serangan ke Irak oleh sekutu yang dikomando AS. Pelaku pasar beralih investasi dari pasar uang dan pasar saham ke investasi emas sehingga permintaan emas melonjak tajam.

Dibandingkan investasi di pasar saham yang cenderung menurun, saat ini tingkat keuntungan yang didapat sekitar 5 persen per tahun, investasi emas dapat menghasilkan tingkat keuntungan sekitar 15 sampai 20 persen per tahun. Walaupun saat ini harga emas sedang terkoreksi, belum adanya titik terang penyelesaian antara AS dan Irak membuat harga emas berpotensi kembali menguat sampai masalah selesai. Saat ini pengaruh terbesar pergerakan harga emas adalah situasi politik dunia.

\section{3) Situasi Ekonomi Dalam Negeri}

$$
\text { Sekitar } 80 \text { persen dari total }
$$
suplai emas digunakan industri perhiasan. Konsumsi perhiasan merupakan pengaruh yang besar pada sisi permintaan.

Ketika kondisi ekonomi meningkat, kebutuhan akan perhiasan cenderung naik. Namun, dari data statistik terlihat kebutuhan akan perhiasan lebih sensitif terhadap naik turunnya harga emas dibanding kan meningkatnya kondisi ekonomi.

Jatuhnya tingkat kebutuhan perhiasan pada masa resesi di tahun 1982-1983 terutamaakibat naiknya harga emas secara simultan. Jatuhnya tingkat kebutuhan perhiasan di masa resesi awal 90-an lebih selaras dengan hal di atas, pada saat itu harga emas menjadi turun.

Situasi ekonomi yang tidak menentu dapat mengakibatkan inflasi tinggi. Emas biasa digunakan sebagai alat lindung nilai terhadap inflasi. Manfaat ini sudah dirasakan investor sejak lama. Dengan emas, investor mendapat perlindungan sempurna terhadap merosotnya daya beli. Ketika tahun 1978-1980 harga emas sedang booming; sementara inflasi di AS naik dari 4 persen menjadi 14 persen, harga emas naik tiga kali lipat.

Akan tetapi, sejak saat itu, emas tidak lagi terlalu efektif secara sempurna digunakan sebagai alat lindung nilai terhadap inflasi. Di Indonesia, dari data yang didapat, tingkat inflasi tidak mempengaruhi 
harga emas. Harga emas lebih banyak dipengaruhi kurs rupiah terhadap dollar.

\section{4) Suku Bunga.}

Ketika tingkat suku bunga naik, ada usaha yang besar untuk tetap menyimpan uang pada deposito ketimbang emas yang tidak menghasilkan bunga (non interestbearing). Ini akan menimbulkan tekanan pada harga emas. Sebaliknya, ketika suku bunga turun, harga emas akan cenderung naik.

Secara teori, jika suku bunga jangka pendek naik, harga emas turun. Di Indonesia teori ini tidak selalu berjalan.

Pada tahun 1998, karena nilai tukar rupiah merosot tajam terhadap mata uang dollar AS, pemerintah menaikkan tingkat suku bunga secara signifikan.Harapannya, menahan laju kenaikan nilai tukar dollar AS. Akibatnya, walaupun tingkat suku bunga naik, harga emas juga naik.

Terlihat tingkat suku bunga tidak terlalu berpengaruh pada harga emas di Indonesia. Tetapi,lebih banyak dipengaruhi harga emas dunia sehingga pengaruh nilai tukar dollar AS terhadap rupiah sangat besar.

3. Kasus - Kasus Prediksi Harga Emas
Beberapa kasus untuk prediksi harga emas itu naik atau turun. Naik atau turun suatu harga emas dipengaruhi oleh beberapa penilaian seperti yang terdapat pada Tabel 1 .

Tabel 1. Data Kasus (Sahabat Pengadaian, 2016).

\begin{tabular}{|c|c|c|c|c|c|}
\hline $\begin{array}{c}\text { Kas } \\
\text { us }\end{array}$ & $\begin{array}{c}\text { Perubah } \\
\text { an Kurs }\end{array}$ & $\begin{array}{c}\text { Situasi } \\
\text { Politik }\end{array}$ & $\begin{array}{c}\text { Situasi } \\
\text { Ekonomi }\end{array}$ & $\begin{array}{c}\text { Suk } \\
\mathbf{u} \\
\text { Bun } \\
\text { ga }\end{array}$ & $\begin{array}{c}\text { Harg } \\
\mathbf{a} \\
\text { Emas } \\
\text { Naik } \\
\text { Atau } \\
\text { Turu } \\
\mathbf{n} \\
\text { (Solu } \\
\text { si) }\end{array}$ \\
\hline 1 & Kuat & Kondusif & Meningkat & Naik & Naik \\
\hline 2 & Lemah & $\begin{array}{c}\text { TidakKond } \\
\text { usif }\end{array}$ & $\begin{array}{c}\text { TidakMene } \\
\text { ntu }\end{array}$ & $\begin{array}{c}\text { Turu } \\
\text { n }\end{array}$ & Turun \\
\hline 3 & Lemah & Kondusif & $\begin{array}{c}\text { TidakMene } \\
\text { ntu }\end{array}$ & $\begin{array}{c}\text { Naik } \\
\text { Naik }\end{array}$ \\
\hline 4 & Kuat & $\begin{array}{c}\text { TidakKond } \\
\text { usif }\end{array}$ & Meningkat & Naik & Naik \\
\hline 5 & Lemah & Kondusif & Menurun & $\begin{array}{c}\text { Turu } \\
\text { n }\end{array}$ & Naik \\
\hline 6 & Kuat & Kondusif & $\begin{array}{c}\text { TidakMene } \\
\text { ntu }\end{array}$ & Naik & Naik \\
\hline 7 & Kuat & Kondusif & Menurun & $\begin{array}{c}\text { Turu } \\
\text { n }\end{array}$ & Turun \\
\hline 8 & Lemah & Kondusif & Meningkat & Naik & Naik \\
\hline 9 & Lemah & $\begin{array}{c}\text { TidakKond } \\
\text { usif }\end{array}$ & Menurun & $\begin{array}{c}\text { Turu } \\
\mathrm{n}\end{array}$ & Naik \\
\hline 10 & Lemah & Kondusif & $\begin{array}{c}\text { TidakMene } \\
\text { ntu }\end{array}$ & $\begin{array}{c}\text { Turu } \\
\mathrm{n}\end{array}$ & Naik \\
\hline
\end{tabular}

4. Metode Representasi

Metode representasi yang digunakan adalah dengan mengkelompokan kasus - kasus kedalam beberapa atribut seperti perubahan kurs, situasi politk, situasi ekonomi, dan suku bunga. Atribut perubahan kurs dibagi menjadi beberapa sub atribut lagi seperti terlihat pada Tabel 2, atribut untuk situasi politik dibagi menjadi beberapa sub atribut terlihat pada tabel 3, atribut untuk situasi ekonomi dibagi menjadi 
beberapa sub atribut terlihat pada Tabel 4, parameter untuk suku bunga dibagi menjadi beberapa sub atribut terlihat pada Tabel 5.

Tabel 2. Atribut Perubahan Kurs.

\begin{tabular}{|c|c|}
\hline No & PerubahanKurs \\
\hline 1 & Kuat \\
\hline 2 & Lemah \\
\hline
\end{tabular}

Tabel 3.Atribut Situasi Politik.

\begin{tabular}{|c|c|}
\hline No & Perencanaan \\
\hline 1 & Kondusif \\
\hline 2 & TidakKondusif \\
\hline
\end{tabular}

Tabel 4. Atribut Situasi Ekonomi.

\begin{tabular}{|c|c|}
\hline No & SituasiEkonomi \\
\hline 1 & Meningkat \\
\hline 2 & Menurun \\
\hline 3 & TidakMenentu \\
\hline
\end{tabular}

Tabel 5. Atribut Suku Bunga.

\begin{tabular}{|c|c|}
\hline No & Sukubunga \\
\hline 1 & naik \\
\hline 2 & turun \\
\hline
\end{tabular}

\section{Desain Sistem}

\section{1) Diagram Context}

Diagram Context merupakan diagram yang menggambarkan aliran data secara garis besar. Diagram ini mencatat data yang masuk ke sistem beserta sumbernya dan informasi apa saja yang dihasilkan sistem beserta tujuan, kemana informasi tersebut akan diberikan. Untuk lebih jelasnya dapat dilihat pada gambar 1 berikut :

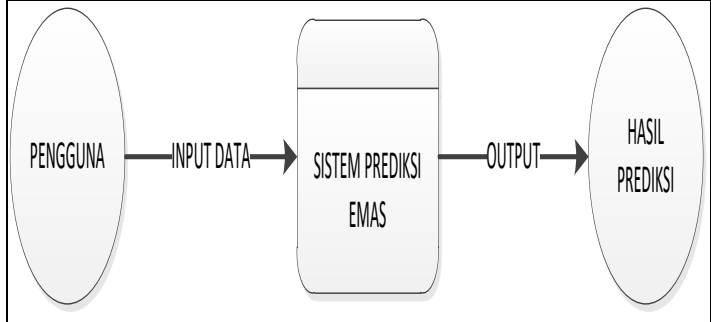

Gambar 1. Diagram Context

2) DFD LEVEL 0

Berikut ini adalah bentuk dari DFD level 0 pada gambar 2 .

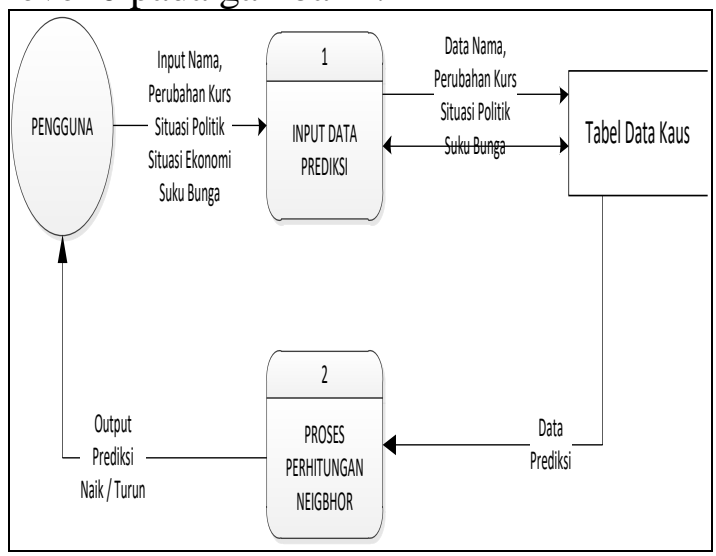

Gambar 2. DFD Level 0.

6. Desain Algoritma Untuk Mencari Penyelesaian Kasus Baru

Algoritma untuk mencari penyeslesain kasus baru digambarkan menggunakan flowchart pada Gambar 3. 


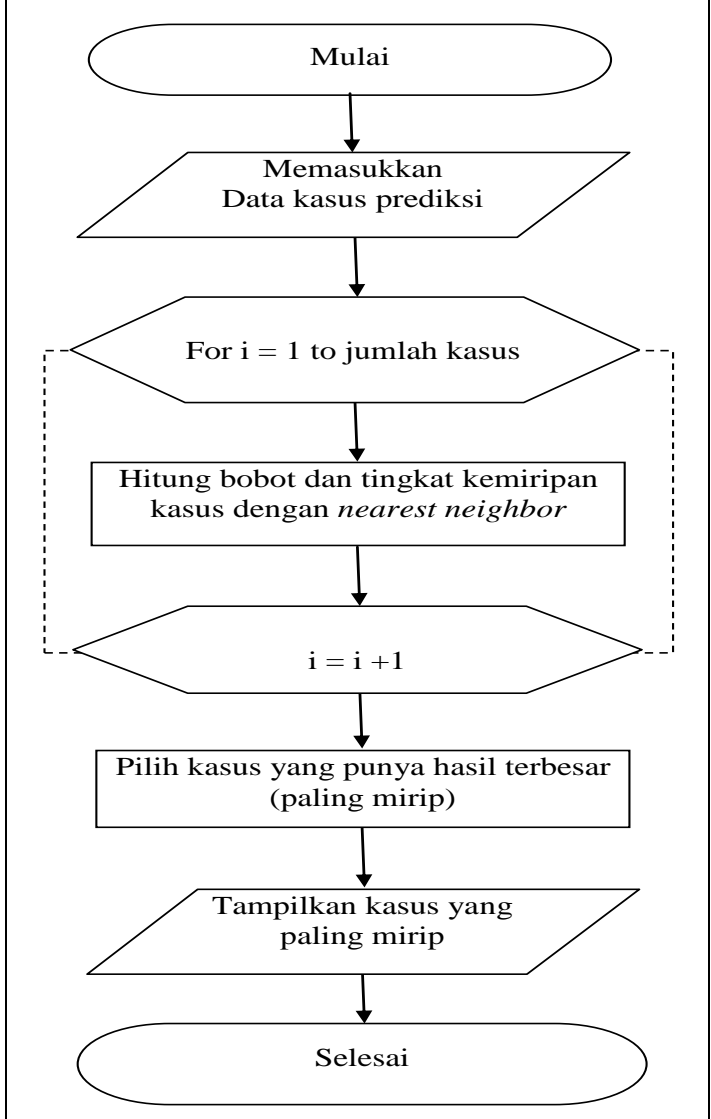

Gambar 3.Flowchart.

Gambar 3 menjelaskan tahapan inferensi case based reasoning pada sistem yang akan dibuat. Pengguna biasa akan melewati 3 tahapan sistem yang menerapkan case based reasoning yaitu:

Tahapan 1: Penguna biasa melakukan input spesifikasi data kasus prediksi emas (misalnya : perubahan kurs = kuat, situasi $\quad$ Politik $=$ kondusif, situasi ekonomi=meningkat, dan suku bunga $=$ naik $)$.

Tahapan 2 :Dilakukan proses retrieve yaitu akan mencari kasus yang memiliki kemiripan paling tinggi berdasarkan spesifikasi yang dimasukkan dengan menggunakan algoritma nearest neighbor retrieval.

Tahapan 3 : Dilakukan proses reuse yaitu menemukan dan mengambil solusi dari kasus lama yang memiliki kemiripan paling tinggi dan menampilkannya sebagai output bagi kasus baru.

\section{Desain Entity Relational Diagram} (ERD)

Dalam Perancangan basis data diperlukan ERD untuk memudahkan dalam membuat struktur tabel basis data. Pada gambar 4 berikut ini ERD aplikasi prediksi harga emas di rancang

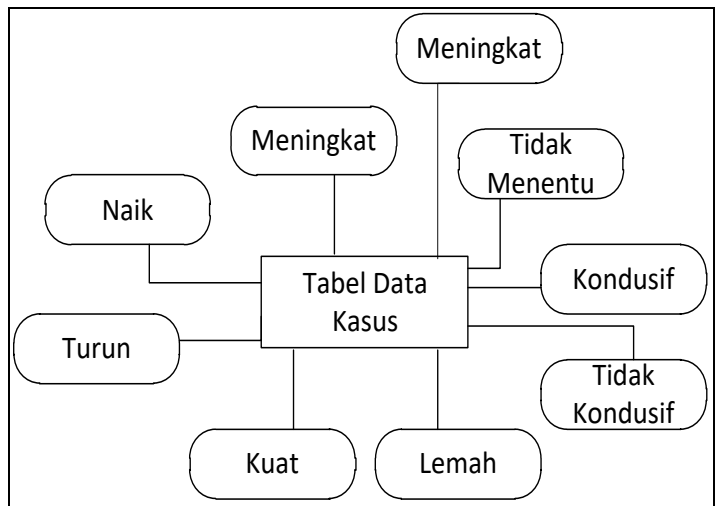

Gambar 4. ERD Aplikasi Prediksi Harga Emas.

8. METODE MENGGUNAKAN RETRIEVAL NEIGHBOR 
Nearest Neighbor adalah pendekatan untuk mencari kasus dengan menghitung kedekatan antara kasus baru dengan kasus lama, yaitu berdasarkan pada kecocokan bobot dari sejumlah atribut yang ada. Misalkan untuk mencari solusi untuk menentukan penyakit tanaman dengan menggunakan solusi dari penyakit tanaman terdahulu. Untuk mencari kasus penyakit tanaman yang akan digunakan, maka dihitung kedekatan kasus penyakit tanaman baru dengan semua kasus penyakit tanaman yang lama. Kasus penyakit tanaman lama dengan kedekatan terbesarlah yang akan diambil solusinya untuk digunakan pada kasus penyakit tanaman baru.

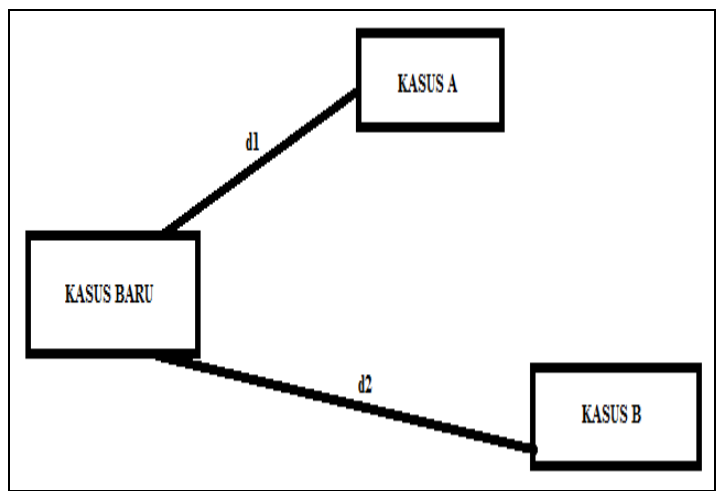

Gambar 5. Ilustrasi Kedekatan Kasus.

Pada Gambar 5 ada terdapat 2 contoh kasus penyakit tanaman lama yaitu kasus A dan kasus B. Ketika ada konsultasi kasus baru, maka solusi yang akan diambil adalah solusi dari penyakit tanaman terdekat dari penyakit tanaman baru. Di misalkan d1 adalah kedekatan antara penyakit tanaman baru dengan kasus penyakit tanaman A, sedangkan d2 adalah kedekatan antara penyakit tanaman baru dengan kasus penyakit tanaman B. Karena d1 lebih dekat dari d2, maka solusi dari penyakit tanaman A yang akan digunakan untuk memberikan solusi untuk penyakit tanaman baru. Adapun rumus yang digunakan untuk melakukan perhitungan pendekatan antara dua kasus dengan menggunakan rumus 2 sebagai berikut :

similarity $\left(T_{s} \mathrm{~S}\right)=\frac{\sum_{i=1}^{n} f\left(T_{i}, S_{i}\right) x w_{i}}{w_{i}}$

Keterangan :

$\mathrm{T}$ : Kasus baru

S : Kasus yang ada dalampenyimpanan

$\mathrm{n}$ : Jumlah atribut dalam setiap kasus

i : Atribut individu antara 1 s.d n

f : Fungsi similarity atribut i antara kasus T dan kasus $\mathrm{S}$

w : Bobot yang diberikan pada atribut ke-i

Kedekatan biasanya berada pada nilai antara 0 sampai 1 . Nilai 0 menunjukan bahwa kedua kasus mutlak tidak mirip, sebaliknya untuk nilai 1 menunjukkan bahwa kasus mirip mutlak. 
Berikut pada Tabel 6 adalah proses dan perhitungan kasus prediksi harga emas untuk retrieval casedan dicoba pada Tabel 1 data kasus:

Tabel 6. Aturan Dalam Kasus Prediksi Harga Emas Untuk RetrievalCase.

\begin{tabular}{|c|c|c|c|c|c|}
\hline $\begin{array}{c}\text { Kasu } \\
\text { s }\end{array}$ & $\begin{array}{c}\text { Perubaha } \\
\text { n Kurs }\end{array}$ & $\begin{array}{c}\text { Situasi } \\
\text { Politik }\end{array}$ & $\begin{array}{c}\text { Situasi } \\
\text { Ekonimi }\end{array}$ & $\begin{array}{c}\text { Suku } \\
\text { Bung } \\
\mathbf{a}\end{array}$ & $\begin{array}{c}\text { Harga } \\
\text { Emas } \\
\text { Naik } \\
\text { Atau } \\
\text { Turun } \\
\text { (Solusi } \\
\text { ) }\end{array}$ \\
\hline 1 & Kuat & $\begin{array}{c}\text { Kondusi } \\
\mathrm{f}\end{array}$ & $\begin{array}{c}\text { Meningka } \\
\mathrm{t}\end{array}$ & Naik & Naik \\
\hline 2 & Lemah & $\begin{array}{c}\text { Tidak } \\
\text { Kondusi } \\
\mathrm{f}\end{array}$ & $\begin{array}{c}\text { Tidak } \\
\text { Menentu }\end{array}$ & Turun & Turun \\
\hline 3 & Lemah & $\begin{array}{c}\text { Kondusi } \\
\mathrm{f}\end{array}$ & $\begin{array}{c}\text { Tidak } \\
\text { Menentu }\end{array}$ & Naik & Naik \\
\hline 4 & Kuat & $\begin{array}{c}\text { Tidak } \\
\text { Kondusi } \\
\mathrm{f}\end{array}$ & $\begin{array}{c}\text { Meningka } \\
\mathrm{t}\end{array}$ & Naik & Naik \\
\hline 5 & Lemah & $\begin{array}{c}\text { Kondusi } \\
\mathrm{f}\end{array}$ & Menurun & Turun & Naik \\
\hline 6 & Kuat & $\begin{array}{c}\text { Kondusi } \\
\mathrm{f}\end{array}$ & $\begin{array}{c}\text { Tidak } \\
\text { Menentu }\end{array}$ & Naik & Naik \\
\hline 7 & Kuat & $\begin{array}{c}\text { Kondusi } \\
\mathrm{f}\end{array}$ & Menurun & Turun & Turun \\
\hline 8 & Lemah & $\begin{array}{c}\text { Kondusi } \\
\mathrm{f}\end{array}$ & Meningka \\
$\mathrm{t}$
\end{tabular}

Atribut atau atribut harga emas adalah atribut tujuan. Bobot antara satu atribut yang lain pada atribut bukan tujuan dapat didefinisikan dengan nilai berbeda. Sehingga diasumsikan bobot untuk tiap-tiap atribut seperti pada Tabel 7.

Tabel 7. Pembobotan Kriteria

\begin{tabular}{|l|c|}
\hline \multicolumn{1}{|c|}{ Atribut } & Bobot \\
\hline Perubahan kurs & 0.75 \\
\hline Situasi politik & 0.25 \\
\hline Situasi ekonomi & 0.5 \\
\hline Suku bunga & 1 \\
\hline
\end{tabular}

Kedekatan antara nilai-nilai dalam atribut juga didefinisikan. Kedekatan nilai atribut perubahan kurs ditunjukan pada Tabel 8, kedekatan nilai atribut situasi politik ditunjukan pada Tabel 9, kedekatan nilai atribut situasi ekonomi ditunjukan pada Tabel 10 dan kedekatan nilai atribut suku bunga ditentukan pada Tabel 11.

Asumsi Nilai 1 dan Nilai 2 Pada Tabel 8 : Untuk Perubahan Kurs

Tabel 8. Kriteria Nilai Atribut Perubahan Kurs

\begin{tabular}{|c|c|c|}
\hline & Nilai_2 & Kedekatan \\
\hline Kuat & Kuat & 1 \\
\hline Kuat & Lemah & 0.5 \\
\hline Lemah & Lemah & 1 \\
\hline Lemah & Kuat & 0.5 \\
\hline
\end{tabular}

Asumsi Nilai 1 dan Nilai 2 Pada Tabel 9 : Untuk Situasi Politik

Tabel 9. Kriteria Nilai Atribut Situasi Politik.

\begin{tabular}{|l|l|c|}
\hline Nilai_1 & Nilai_2 & Bobot \\
\hline Kondusif & Kondusif & 1 \\
\hline Kondusif & $\begin{array}{l}\text { Tidak } \\
\text { kondusif }\end{array}$ & 0.4 \\
\hline $\begin{array}{l}\text { Tidak } \\
\text { kondusif }\end{array}$ & $\begin{array}{l}\text { Tidak } \\
\text { kondusif }\end{array}$ & 1 \\
\hline $\begin{array}{l}\text { Tidak } \\
\text { kondusif }\end{array}$ & Kondusif & 0.4 \\
\hline
\end{tabular}

Asumsi Nilai 1 dan Nilai 2 Pada Tabel 10 : Untuk Situasi Ekonomi

Tabel 10. Kedekatan Nilai Atribut Situasi Ekonomi.

\begin{tabular}{|l|l|c|}
\hline Nilai_1 & Nilai_2 & Kedekatan \\
\hline Meningkat & Meningkat & 1 \\
\hline Meningkat & Menurun & 0.6 \\
\hline Meningkat & Tidak menentu & 0.7 \\
\hline Menurun & Menurun & 1 \\
\hline Menurun & Meningkat & 0.6 \\
\hline Menurun & Tidak menentu & 0.7 \\
\hline $\begin{array}{l}\text { Tidak } \\
\text { menentu }\end{array}$ & Tidak menentu & 1 \\
\hline
\end{tabular}




\begin{tabular}{|l|l|c|}
\hline $\begin{array}{l}\text { Tidak } \\
\text { menentu }\end{array}$ & Menurun & 0.7 \\
\hline $\begin{array}{l}\text { Tidak } \\
\text { menentu }\end{array}$ & Meningkat & 0.7 \\
\hline
\end{tabular}

Asumsi Nilai 1 dan Nilai 2 Pada

Tabel 11 : Untuk Suku Bunga

Tabel 11. Kedekatan Nilai Atribut Suku Bunga.

\begin{tabular}{|l|l|c|}
\hline Nilai_1 & Nilai_2 & Kedekatan \\
\hline Naik & Naik & 1 \\
\hline Naik & Turun & 0.3 \\
\hline Turun & Turun & 1 \\
\hline Turun & Naik & 0.3 \\
\hline
\end{tabular}

Misalkan ada kasus baru prediksi harga emas dengan nilai atribut sebagai berikut :

Perubahan kurs : Kuat

Situasi Politik : Kondusif

Situasi Ekonomi : Tidak menentu

Suku Bunga $\quad$ : Turun

Untuk memprediksi apakah harga emas tersebut akan naik atau turun dilakukan dengan langkah - langkah berikut :

Menghitung kedekatan kasus baru dengan kasus nomor 1.

Diketahui :

$\mathrm{a}=$ Kedekatan nilai atribut perubahan kurs (Kuat dengan kuat) : 1

$\mathrm{b}=$ Bobot atribut perubahan kurs : 0.75

$\mathrm{c}=$ Kedekatan nilai atribut situasi politik (kondusif dengan kondusif) : 1 $\mathrm{d}=$ Bobot atribut situasi politik : 0.25

$\mathrm{e}=$ Kedekatan nilai atribut situasi ekonomi (meningkat dengan tidak menentu) : 0.7

$\mathrm{f}=$ Bobot atribut situasi ekonomi :

0.5

$\mathrm{g}=$ Kedekatan nilai atribut suku bunga (Naik dengan turun): 0.3

$\mathrm{h}=$ Bobot atribut situasi ekonomi : 1

Dihitung :

$$
\begin{aligned}
& \text { Jarak }=\frac{(a * b)+(o * d)+(a * f)+(g * h)}{b+d+f+h} \\
& \text { Jarak }= \\
& \frac{(1 * 0.75)+(1 * 0.25)+(0.7 * 0.5)+(0.3 * 1)}{0.75+0.25+0.5+1} \\
& \text { Jarak }=\frac{1.65}{2.5} \\
& \text { Jarak }=0.66
\end{aligned}
$$

Untuk perhitungan kasus baru dengan kasus nomor 2 sampai kasus no 10 ditunjukan tabel 13 dibawah ini.

Tabel 13. Perhitungan Kedekatan Kasus Baru Dengan Kasus Lama.

\begin{tabular}{|c|c|c|c|c|c|c|}
\hline $\begin{array}{c}\text { Ka } \\
\text { sus }\end{array}$ & $\begin{array}{c}\text { Peru } \\
\text { baha } \\
\text { nKur } \\
\text { s }\end{array}$ & $\begin{array}{c}\text { SituasiP } \\
\text { olitik }\end{array}$ & $\begin{array}{c}\text { Situa } \\
\text { siEko } \\
\text { nomi }\end{array}$ & $\begin{array}{c}\text { Suku } \\
\text { Bung } \\
\text { a }\end{array}$ & $\begin{array}{c}\text { HargaE } \\
\text { masNai } \\
\text { kAtauT } \\
\text { urun } \\
\text { (Solusi) }\end{array}$ & $\begin{array}{c}\text { JarakD } \\
\text { enganK } \\
\text { asusBar } \\
\mathbf{u}\end{array}$ \\
\hline 1 & 1 & 1 & 0.7 & 0.3 & Naik & 0.66 \\
\hline 2 & 0.5 & 0.4 & 1 & 1 & Turun & 0.79 \\
\hline 3 & 0.5 & 1 & 1 & 0.3 & Naik & 0.57 \\
\hline 4 & 1 & 0.4 & 0.7 & 0.3 & Naik & 0.6 \\
\hline 5 & 0.5 & 1 & 0.7 & 1 & Naik & 0.79 \\
\hline 6 & 1 & 1 & 1 & 0.3 & Naik & 0.72 \\
\hline 7 & 1 & 1 & 0.7 & 1 & Turun & 0.94 \\
\hline 8 & 0.5 & 1 & 0.7 & 0.3 & Naik & 0.51 \\
\hline 9 & 0.5 & 0.4 & 0.7 & 1 & Naik & 0.73 \\
\hline 10 & 0.5 & 1 & 1 & 1 & Naik & 0.85 \\
\hline & & & & & & \\
\hline
\end{tabular}


Setelah perhitungan kedekatan kasus baru dengan kasus yang lama dihitung, langkah selanjutnya adalah memilih kasus dengan kedekatan terdekat. Dari tabel 8 diatas terlihat bahwa nilai tertinggi adalah kasus nomor 7 . Berarti kasus yang terdekat dengan kasus yang baru adalah kasus nomor 7 . Berdasarkan hasil perhitungan pada tabel 11, maka klasifikasi dari kasus 7 yang digunakan untuk memprediksi kasus baru, dengan kemungkinan nilai emas akan turun.Berikut adalah hasil solusi dari perhitungan.

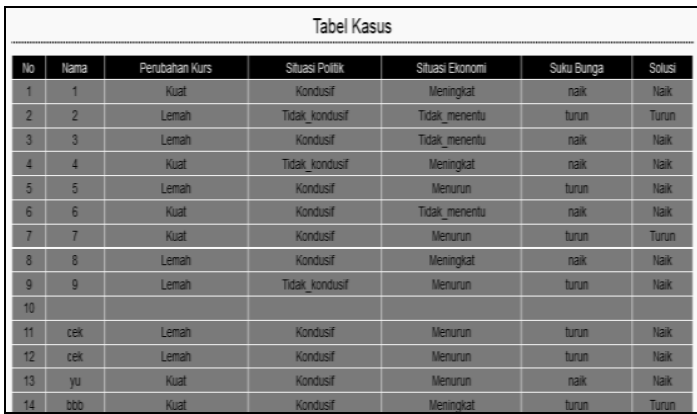

Gambar 6. Hasil Solusi Perhitungan di Aplikasi.

\section{HASIL DAN PEMBAHASAN}

\section{Halaman Utama}

Bagi pengguna cara pengoperasian program ini sangatlah penting supaya bisa mengetahui harga emas. Berikut ini adalah tampilan awal ketika pengguna biasa mengakses halaman web. Terdapat 4 menu pilihan selain nama yang bisa kita lihat pada gambar 7 ini.

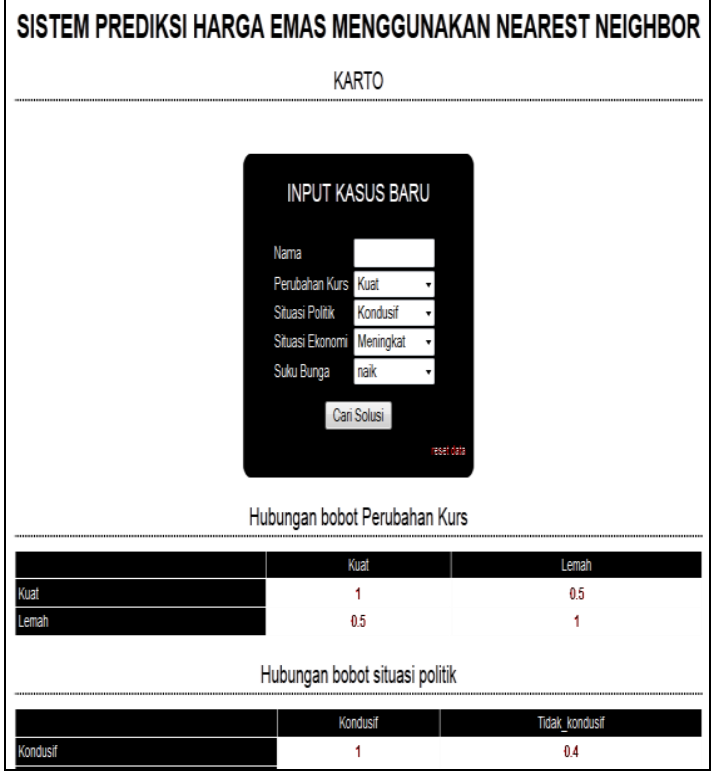

Gambar 7. Halaman Utama.

\section{Halaman Hubungan Bobot Perubahan Kurs}

Bagi penguna yang ingin mengetahuihasil perhitungan bobot untuk perubahan kurs, berikut tampilannya pada Gambar 8 .

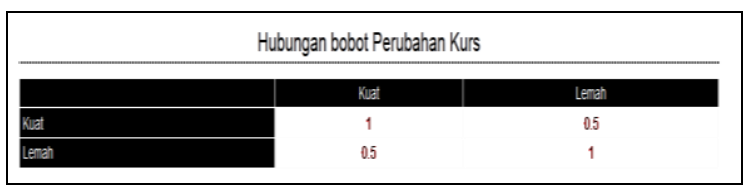

Gambar 8. Halaman Hubungan Bobot Perubahan Kurs.

\section{Halaman Hubungan Bobot Situasi Politik}

Bagi penguna yang ingin mengetahui hasil perhitungan bobot untuk situasi politik, berikut tampilannya pada Gambar 9. 


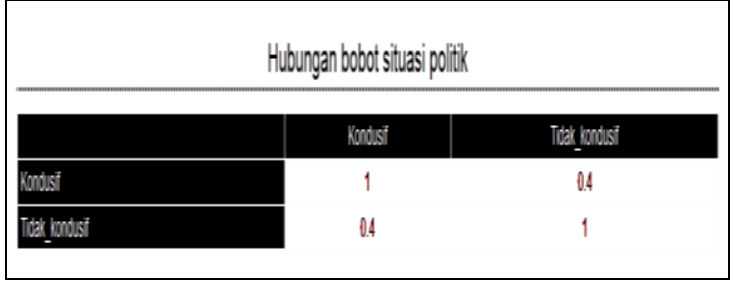

Gambar 9. Halaman Hubungan Bobot Situasi Politik.

\section{Halaman Hubungan Bobot Situasi Politik}

Bagi penguna yang ingin mengetahui hasil perhitungan bobot untuk situasi ekonomi, berikut tampilannya pada Gambar 10.

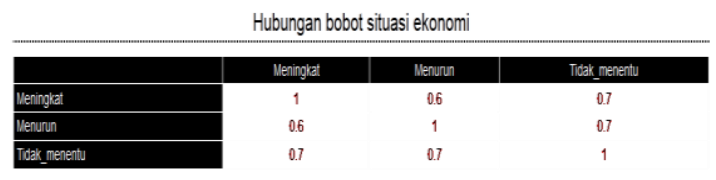

Gambar 10. Halaman Hubungan Bobot Situasi Ekonomi.

\section{Halaman Hubungan Bobot Suku Bunga}

Bagi penguna yang ingin mengetahui hasil perhitungan bobot untuk suku bunga, berikut tampilannya pada Gambar 11.

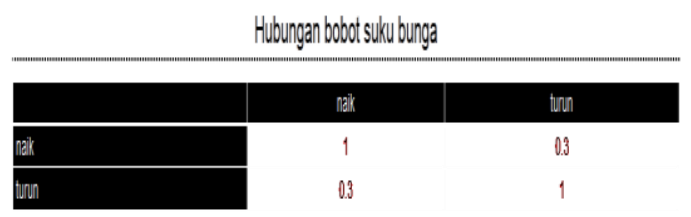

Gambar 11. Halaman Hubungan Bobot Suku Bunga.

\section{Halaman Hasil Tabel Kasus}

Bagi penguna yang ingin mengetahui hasil akhir perhitungan, berikut tampilannya pada gambar 12 .
Tabel Kasus

\begin{tabular}{|c|c|c|c|c|c|c|}
\hline 10 & Nama & Percobanan Kus & Stasi Politix & Sttuas Ekanomi & Sulu Bunga & Solusi \\
\hline 1 & 1 & Kuat & Kondusff & Meninglat & nakk & Nak \\
\hline 2 & 2 & Lemah & Tidak _kondust" & Tidak menerntu & twon & Turn \\
\hline 3 & 3 & Lemah & Kondusfi & Tobak menertus & nakik & lak \\
\hline 4 & 4 & Kuat & Toak _londusfi & Neninglat & nak & Nak \\
\hline 5 & 5 & Lemah & Kondusf & Menurun & toun & Nak \\
\hline 6 & 6 & Kual & Kondusf & Tidaks menentu & nak & Nakk \\
\hline 7 & 7 & Kuat & Kondusfi & Menurun & tuon & Turn \\
\hline 8 & 8 & Lemah & Kondusit & Neninglat & nak & Nak \\
\hline 9 & 9 & Lemah & Todak _ondust & Menurun & tuon & lak \\
\hline \multicolumn{7}{|l|}{10} \\
\hline 11 & cek & Lemah & Kondusf & Menurun & turn & Nak \\
\hline 12 & cek & Lemah & Kondusf & Menurn & tunn & Nak \\
\hline 13 & y & Kuat & Kondusit & Menuun & nak & llak \\
\hline 14 & bob & Kuat & Konususf & Neninglat & tuon & Turn \\
\hline
\end{tabular}

Gambar 12. Halaman Hasil Tabel Kasus.

\section{KESIMPULAN DAN SARAN}

Pada penelitian ini telah berhasil dibuat sebuah aplikasi untuk prediksi harga emas dengan memanfaatkan metode Nearest Neighbor Retrieval. Aplikasi ini dapat membantu pengguna dalam mengetahui hasil prediksi harga emas itu mahal atau murah denga dilihat dari segi situasi ekonomi, suku bunga, situasi politik, dan perubahan kurs. Aplikasi ini juga dapat menjadi pelengkap apabila pengguna ingin mengetahui informasi harga emas. Dan aplikasi prediksi harga emas ini pun dapat berjalan dengan baik.

Saran dari penulis untuk pengembangan aplikasi prediksi harga emas ini lebih lanjut adalah aplikasiinidapatdikembangkandengan menambahkan metode yang lainnya seperti Fuzzy, JST, Algoritma Genetika dan juga dilengkapi dengan informasi- 
informasi yang lebih akurat, sehingga

pengguna dalam memprediksi menjadi

lebih mudah untuk mengetahui informasi harga emas.

Pengembanganaplikasikedepannyaadala

hperludilakukanpadasetiapsystemoperas iperangkatmobile

yang

terintegrasisehinggapenggunaanaplikasi

menjadilebihluasdanbukanhanyapada

berbasis web saja.

\section{DAFTAR PUSTAKA}

Antony, Rojali, dan Ngarap I. M. 2013. Perancangan Program Prediksi Harga Emas Dengan Menggunakan Metode Adaptive Neuro-Fuzzy Inference System. Thesis.BINUS University. Jakarta.

Info Peluang Usaha. 2015. http://infopeluangusaha.org/simak -prediksi-harga-emas-di-tahun2015. 3 Maret 2016 (09.00)

Kesumadan Niti P., 2012. Analisis Pengaruh Kurs Rupiah, Harga Emas Dunia Dan Harga Minyak Dunia Terhadap IHSG Sektor Pertambangan di BEI. Universitas Sriwijaya Fakultas Ekonomi Palembang.Periode JanuariDesember 2010.

Reza N., H, Rizal R., I., dan Oky D., N. 2013.Implementasi Jaringan Syaraf Tiruan Perambatan Balik Untuk Memprediksi Harga Logam Mulia Emas Menggunakan Algoritma Levenberg Marquardt, Universitas Diponegoro. http://eprints.undip.ac.id/39333/1/ Makalah_TA_Reza_Najib_(L2N0 08037).pdf. $17 \quad$ April 2016 (10.00).

Sahabat Pengadaian,2016.Faktor yang mempengaruhi naik turunya harga emas, http://sahabatpegadaian.com/ema s/5-faktor-harga-emas-naik-danturun.16 April 2016 (10.30).

Sinta, 2015, Aplikasi Prediksi Kenaikan Harga Emas Dunia Dengan Menggunakan Metode Backpropagation. Tugas Akhir, Universitas Kristen Duta Wacana (UKDW). D. I.Yogyakarta.

Yofianto, E. 2010.K-Nearest Neighbor (KNN).Buku TA. 